\title{
Land Use Change Monitoring as a Task of Local Government Administration in Poland
}

\author{
Tomasz Noszczyk ${ }^{1}$ \\ 1 Department of Land Management and Landscape Architecture, Faculty of Environmental Engineering \\ and Land Surveying, University of Agriculture in Krakow, Balicka 253c Str., 30-149 Krakow, Poland, e-mail: \\ tomasz.noszczyk@urk.edu.pl
}

\begin{abstract}
The paper looks into the issues related to the monitoring of land use change by voivodeship marshals in Poland. The author intended to provoke the academic circles to devote more attention to this matter as well. The analysis involved the publicly available materials and the information from websites of 16 marshal offices and Polish acts of law made available in the Online Database of Legal Acts. The paper includes an analysis of the changes in land use monitoring legislation in Poland and when the obligation was first introduced. It was further verified whether all the offices publish the documents relevant to the monitoring. It was found out that half of the voivodeships failed to publish the materials related to the performance of this statutory task. This results in a varied availability of the documents and prevents potentially interested parties from familiarising themselves with the land use change monitoring issues.
\end{abstract}

Keywords: land use change, land use, monitoring, voivodeship marshal, data availability

\section{INTRODUCTION}

The land use change processes are inevitable [Karimi et al. 2017] and determined by the necessary growth of urbanisation, transport, services, and various types of production, including agricultural production [Woch 2014]. Due to the fact that the phenomenon is an important part of environmental change studies, it is a popular study problem in Poland [Poławski 2009, Noszczyk et al. 2017], Europe [Bouma et al. 1998, van Vliet et al. 2015], Asia [Van Paassen et al. 2007, Deng and Li 2016], Africa [Stephenne and Lambin 2001, Kleemann et al. 2017], or Americas [Schneider and Pontius 2001, Chen and Dirmeyer 2017].

Land use in Poland has been changing rapidly, especially after 1989 when the sociopolitical transformation took place [Bürgi et al. 2010, Salata et al. 2015]. The current structure of land use has been shaped by the historical events as well as socioeconomic and political changes [Poławski 2009]. Since the end of the 1980s, Poland has been undergoing deep political [Olsze- wski et al. 2015], economic, and social transformations [Dannenberg and Kuemmerle 2010]. Privatisation of state ownership and advent of small and medium enterprises were important factors of the transformation [Łowicki 2008]. According to Irwin and Geoghegan [2001], the economic changes are closely reflected in the land use structure, both locally and at the regional level. They are first and foremost visible in housing and service development on urban outskirts [Cegielska et al. 2017] as well as construction of new and modernisation of existing roads [Poławski 2009].

Agricultural areas also experience rapid changes in land use [Woch and Woch 2014]. The surface area of land used for agricultural purposes is reduced, as substantial areas are earmarked for purposes other than agriculture [Krasowicz et al. 2011]. Certain spatial transformations result from the new possibilities related to the Common Agricultural Policy of the EU [Kluba 2013, Olszewski et al. 2015].

The pace and trends of land use change force authorities responsible for spatial planning on the 
regional and local level to determine the causes of the harmful phenomena and to develop countermeasures [Łowicki 2008]. According to Woch and Woch [2014], the dynamics and spatial location of land use change should be monitored continuously, which is a precondition for rational spatial management. Moreover, it is necessary to monitor the current state and trends in changes regularly and to identify various threats to the rational management of soil resources. These constitute essential challenges for academics and practitioners as well as crucial strategic directions of action [Krasowicz et al. 2011].

In Poland, the monitoring of land use change is the task of the voivodeship marshal. The marshal is the president of the local voivodeship government (executive body). They manage the ongoing operations of the voivodeship and represent it before third parties. The marshal is a civil representative of the local government administration independent of the central government. This monitoring obligation is imposed by the Geodesic and Cartographic Law Act (GCL) [Act 1989]. The issue of land change monitoring and sharing this information by marshals has been poorly investigated and was not a popular study subject. Hence, the purpose of the paper is to investigate the availability of information on the performance of the statutory obligation, i.e. monitoring of land use change, by voivodeship marshals and publication of relevant documentation. The author intended to provoke the academic circles to draw more attention to this matter and to fill in the gap in Polish literature as well.

\section{MATERIAL AND METHODS}

The first step was to select the study objects. All 16 voivodeships of Poland were assumed to be analysed as regards the availability of information on the performance of the statutory duty to monitor land use change. For this purpose, the materials and information on marshal offices' websites, land surveying departments were used, as these units are responsible for monitoring land use change. It was verified whether voivodeship marshals make such data available to the public online and whether it is generally and readily available to the citizens.

Furthermore, legal acts were used in the paper to analyse how the Polish legislation changed as regards land use change monitoring. They were also the basis for establishing when and with which regulations was the obligation introduced.

All data was acquired from the materials available on websites of marshal offices in Poland. The legal acts and relevant information were obtained from the Online Database of Legal Acts (Internetowy System Aktów Prawnych, ISAP), which offers bibliographic descriptions and content of legal acts published in the official publications of the Prime Minister [ISAP 2017].

\section{RESULTS AND DISCUSSION}

\section{The current legal state of land use change monitoring}

According to the current legal state in Poland (September 2017), the voivodeship marshal is the geodesic and cartographic administration authority that - with the help of the voivodeship land surveyor - forms the Geodesic and Cartographic Service [Act 1989]. The Act of 17 May 1989 Geodesic and Cartographic Law (GCL), in particular, its Article 7c sets out the tasks of the voivodeship marshal, which include the monitoring of land use and soil quality change (Fig. 1).

Note that the first wording of the GCL adopted by the Sejm on 17 May 1989 did not include the regulations on land use change monitoring. The administrative subdivision of Poland was different at that time. The country was divided into 49 voivodeships and further into municipalities, while districts (powiat in Polish) were removed from the structure [Act 1975]. Note that the local agency of the central government in a voivodeship was at the time the voivode, whereas the office of voivodship marshal was non-existent [Act 1975]. This subdivision, introduced with the Act of 1975, was in force until 1 January 1999 when another administrative reform brought a three-tier subdivision of Poland. As a result, 16 voivodeships, 315 districts, and 2489 municipalities have been established [Act 1998a, Chaba 2016]. Apart from central government administration headed by the voivode, the voivodeship has been introduced as a local government unit with a local government headed by the marshal.

The administrative reform of 1999 necessitated the adjustments of numerous regulations. The GCL also had to be adapted to the new environment and was amended multiple times in that period. Note that the amendment of 24 July 


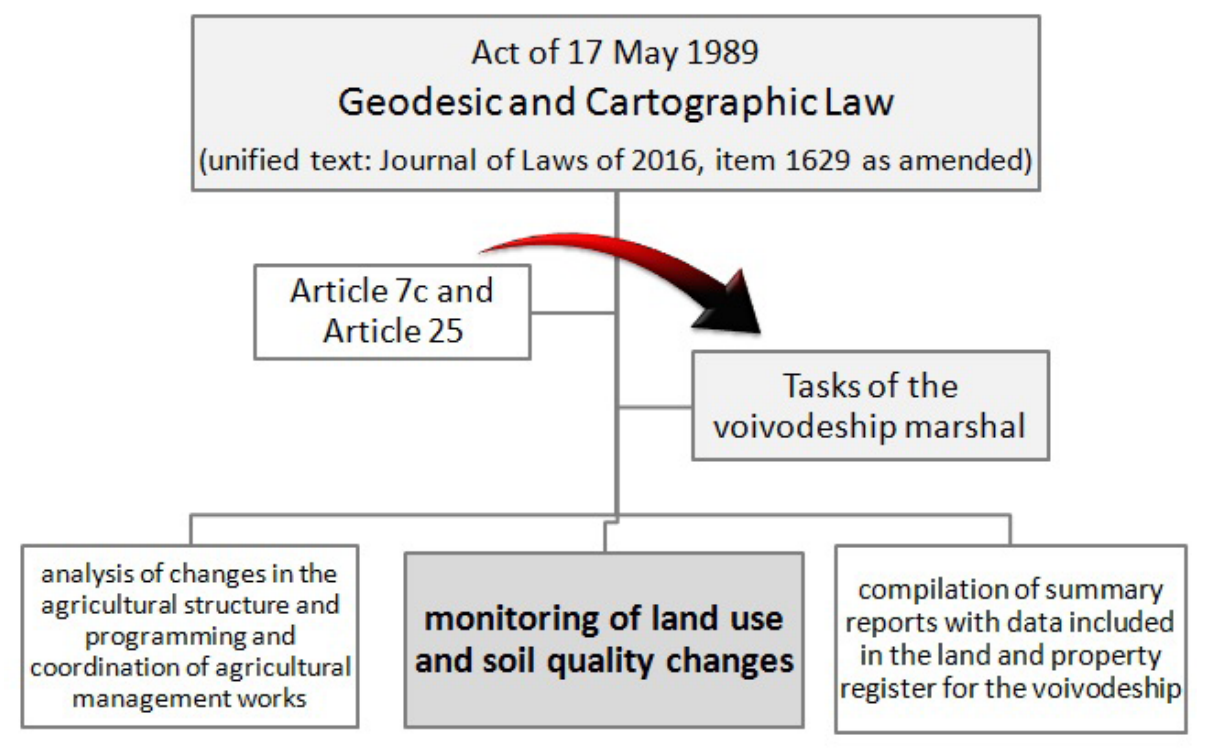

Fig. 1. Examples of tasks of the voivodeship marshal in accordance with the GCL

1998 introduced Article 6a to the GCL. It defines which authorities make up the Geodesic and Cartographic Service [Act 1998b]. The voivodeship marshal was listed there. This amendment introduced Article 7c as well, which sets out three primary tasks of the marshal [Act 1998b]. At the time, the legislator did not include the land use change monitoring among them. The duty was introduced into the GCL with the Act of 21 January 2000 on the amendment of some acts relevant to the functioning of public administration [Act 2000]. Therefore, it has to be stated clearly that land use and soil quality monitoring has been present in the Polish legislation as the duty of the voivodeship marshal since January 2000 and effectively since 23 February 2000 when the act was published [Act 2000].

Another regulation of the GCL, Article 25(2) states that voivodeship marshals compile the summary reports of data that are included in the land and property register for the voivodeship [Act 1989]. Note that this regulation, albeit in a slightly different form owing to a different administrative subdivision, has been in force since 1989 when the GCL was first introduced. Still, the regulations on annual reports of land and property can be found as early as in Article 11 of the Decree of 2 February 1955 on the land and property register [Decree 1955]. These issues were then specified in more detail in the Instructions of the Minister of Agriculture of 1955 [Instructions 1955] and the Instructions of the Minister of Municipal Services of 1956 [Instructions 1956].
They are currently regulated by the Regulation of the Minister of Regional Development and Construction of 29 March 2001 on the land and property register [Regulation 2001]. It is an important matter because marshal offices conduct the analyses for land use change monitoring based on the data in the summary reports [see e.g. Dawidowicz 2010, Analiza 2016a, http://wgik.dolnyslask.pl/ wojewodzkiezestawienia].

\section{Availability of information. Analysis of 16 voivodeships}

The analysis of websites of 16 marshal offices in Poland, including the land surveying departments indicates that the information published there is not readily available to citizens. The actions necessary to obtain it are counterintuitive. It takes much time to find specific relevant materials (if at all available). Moreover, not all marshal offices publish the data or documents on land use change monitoring. The Results of the analysis pertaining to the official websites are shown in Table 1.

Note that no analysis or documents resulting from the statutory duty of land use change monitoring were found on the websites of eight marshal offices, with two of them publishing only the information that such documents are drafted (Tab. 1). For some voivodeships (Łódzkie, Opolskie, Świętokrzyskie) the land use maps were found on spatial information system websites or geoportals. It should be stated clearly that the fact 
Table 1. Documents relevant to land use change monitoring made available on marshal offices' websites in Poland (as of September 2017)

\begin{tabular}{|c|c|c|}
\hline Name of the voivodeship & Materials published & Type of document \\
\hline Dolnośląskie & YES, seldom selected analyses & $\begin{array}{l}\text { Analysis of the land use change in the Dolnośląskie } \\
\text { Voivodeship over the last } 40-50 \text { years (1970-2010 by } \\
\text { the Institute of Soil Science and Plant Cultivation in } \\
\text { Puławy) }\end{array}$ \\
\hline Kujawsko-Pomorskie & YES, available for 2015 and 2016 & $\begin{array}{l}\text { Analysis of the land ownership structure and land use in } \\
\text { the Kujawsko-Pomorskie Voivodeship in } 20 \ldots\end{array}$ \\
\hline Lubelskie & not found & - \\
\hline Lubuskie & not found & - \\
\hline Łódzkie & $\begin{array}{l}\text { YES, only maps on geoportal for } \\
2002 \text { and } 2015\end{array}$ & Possession structure, use structure as of $20 \ldots$ \\
\hline Małopolskie & $\begin{array}{l}\text { not found, only information that } \\
\text { analyses are performed }\end{array}$ & $\begin{array}{l}\text { Analysis of the land possession and land use structure } \\
\text { in the Małopolskie Voivodeship }\end{array}$ \\
\hline Mazowieckie & $\begin{array}{l}\text { YES, available for } 2013,2015 \text {, and } \\
2016\end{array}$ & $\begin{array}{l}\text { Analysis of the land ownership structure and land use in } \\
\text { the Mazowieckie Voivodeship }\end{array}$ \\
\hline Opolskie & $\begin{array}{l}\text { YES, only maps on geoportal for } \\
2007,2009 \text { and 2011-2016 }\end{array}$ & $\begin{array}{l}\text { Land possession in districts, land use structure in } \\
\text { districts in } 20 \ldots\end{array}$ \\
\hline Podkarpackie & not found & - \\
\hline Podlaskie & not found & - \\
\hline Pomorskie & not found & - \\
\hline Śląskie & YES, annually & $\begin{array}{l}\text { Analysis of the land ownership structure and land use in } \\
\text { the Śląskie Voivodeship in } 20 \ldots\end{array}$ \\
\hline Świętokrzyskie & $\begin{array}{l}\text { YES, only a map in SIS (without a } \\
\text { year) }\end{array}$ & $\begin{array}{l}\text { Land use map based on LANDSAT satellite imagery } \\
\text { classification }\end{array}$ \\
\hline Warmińsko-Mazurskie & $\begin{array}{l}\text { YES, annually (analyses available } \\
\text { since 2013) }\end{array}$ & $\begin{array}{l}\text { Analysis of the agricultural structure and land use in the } \\
\text { Warmińsko-Mazurskie Voivodeship as of } 1.01 .20 \ldots\end{array}$ \\
\hline Wielkopolskie & not found & - \\
\hline Zachodniopomorskie & $\begin{array}{l}\text { not found, only information that } \\
\text { analyses are performed }\end{array}$ & $\begin{array}{l}\text { Analysis of the changes in agricultural land use surface } \\
\text { areas in the Zachodniopomorskie Voivodeship based } \\
\text { on summary annual reports of the land and property } \\
\text { register (1.01.2002-1.01.2010) }\end{array}$ \\
\hline
\end{tabular}

that the materials are not available on the websites does not mean that the voivodeship marshals do not perform their duties. They may draft these documents thus conforming to their obligations, but without publishing them online. This makes the access to the analyses differ across voivodeships and prevents potentially interested parties from using the materials.

On the basis of the analysis of documents made available by eight marshal offices, it was found that the marshals perform their duties using the registry data from summary reports. Their scopes and deadlines for completion by relevant authorities are shown in Figure 2. It is also confirmed by the information on the website of the Śląskie Voivodeship Marshal Office: 'The analysis was prepared based on district aggregate data included in the land and property register provided by starosts (...)' [http://www.slaskie.pl/strona_n. php?jezyk $=$ pl\&grupa $=3 \&$ dzi $=1279014625 \& \overline{\mathrm{id}}$ menu $=533$ ]. A similar note is displayed on the website of the Dolnośląskie Voivodeship Marshal Office [http://wgik.dolnyslask.pl/web/start/dsip/ bazy-tematyczne/struktura-uzytkowania-grun- tow] or of the Warmińsko-Mazurskie Voivodeship Marshal Office [Analiza 2014].

Marshals indicate specific actions taken regarding their duty as a proof that it is performed. The information in the Public Information Bulletin of the Małopolskie Voivodeship Marshal Office is an example worth noting [Public Information Bulletin 2017]. It states that the marshal performs the following activities to ensure land use and soil quality change in rural areas:

1. Creation of databases based on the land register report, soil classification and mapping report, as well as field inspection, for example as regards afforestation, marginal land, natural disaster consequences, protection zones, and ecological sites

2. Monitoring of land use and soil quality changes

3. Analysis of changes in land use and soil quality (once a year)

4. Visual, descriptive, and tabular presentation of the changes in land use and soil quality

5. Preparation of a report and final conclusions

6. Notification of local governments about the analysis results 


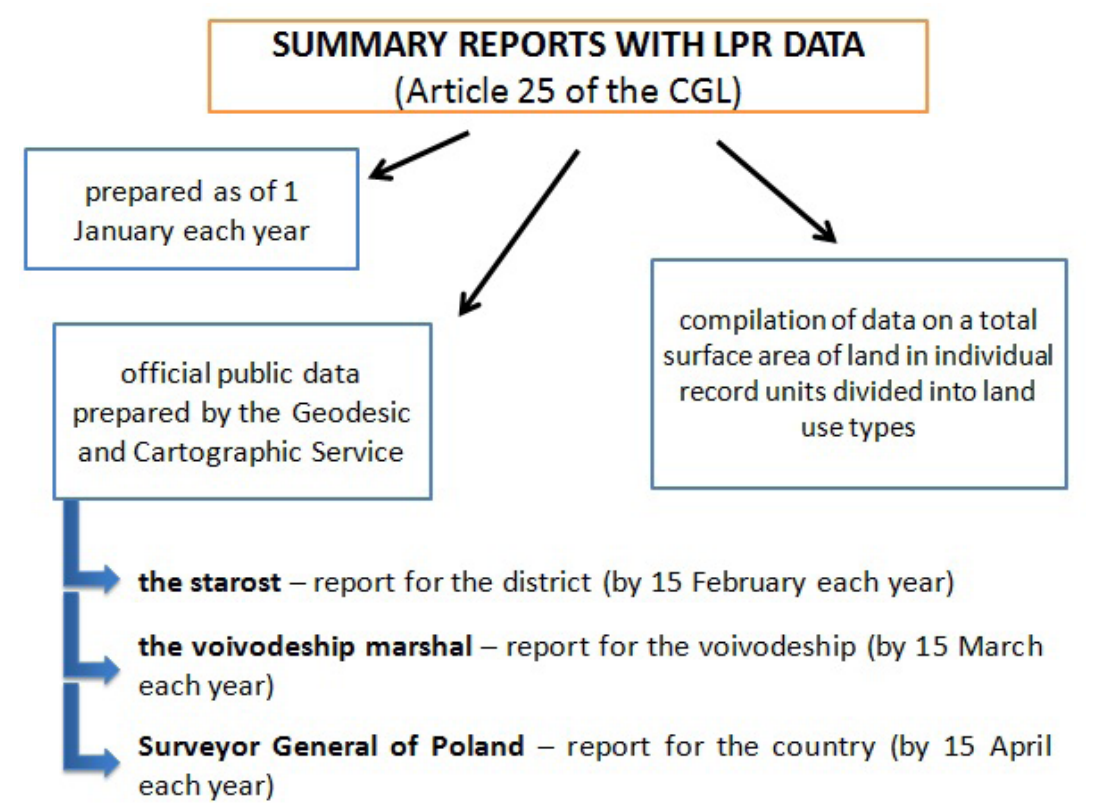

Fig. 2. Information and deadlines for aggregate summaries of data under the land and property register (LPR)

\section{Preparation of a report for voivodeship local government}

Note that most marshals perform their statutory duty by analysing the current land use for a given year and compare it with the data for the previous year (rarely several years back) [Analiza 2014]. This opinion is substantiated by an analysis of materials on websites of several voivodeships (including Śląskie and Warmińsko-Mazurskie). Most marshals analyse the land use changes yearon-year only in their monitoring activities. Sometimes, the current state is compared to the data from, for example, 5 years back [Analiza 2016a]. Virtually no marshal office (apart from the one in the Mazowieckie Voivodeship) carries out regular long-term analyses of year-on-year changes. It is reflected in the documents published on the websites where voivodeships that do publish the land use change monitoring analyses follow the schema described above [see: Analiza 2014, Analiza 2016b].

The statutory duty of monitoring land use changes is a vital task not to be taken lightly. The primary reason is that the monitoring of the changes is indispensable for a rational space and soil management in the voivodeship. A similar view was expressed by Krasowicz et al. [2011] and Woch and Woch [2014]. The Mazowieckie Voivodeship stands out in this regard. Its two analyses (from 2015 and 2016) take into account land use changes since 2002 [Struktura 2016].
Documents prepared this way may be used to diagnose the change trends in agricultural structure over several investigated years and may be useful to many individuals and institutions that operate in the general field of structural changes [Analiza 2016b, p. 6]. They may also assist the decisionmaking process by voivodeship marshals as regards, for example, the agricultural management works, rural development prognosis [Olszewski et al. 2015] or conversion of land from the agricultural production to other uses [Noszczyk et al. 2017]. The monitoring of land use change is a real need in Poland. Cegielska et al. [2017] indicate additionally a need to constantly monitor the changes, which is necessary for taking planning actions to reduce the negative effects of use changes (in particular anthropogenic pressure). It is also an essential challenge for academics and practitioners and at the same time, a crucial strategic direction of action [Krasowicz et al. 2011].

\section{CONCLUSIONS}

It should be stressed that after the sociopolitical transformation in Poland, the rational management of land and sustainable development became a vital issue for the socioeconomic growth. The constantly changing surface areas of individual types of land use calls for monitoring. What is more, the land use change monitoring is a real need in Poland and it is important to share 
the analyses with citizens. Regrettably, it is not always the case.

The actions taken by the local government authorities mainly involve the observation of the current land use structure in juxtaposition with the one of the previous years (or, rarely, of several previous years). It is confirmed by the materials on official websites. This approach, however, does not guarantee that the duty is performed appropriately and does not lead to the correct conclusions or insights from the analyses. Adequate decisions or preventive measures may not be made or taken in such circumstances. Moreover, not all marshal offices share their analyses with the public, for example by using their websites. This prevents potentially interested parties from using such materials. The author hereby calls for such data to be shared and published online more widely.

In light of the above, it is vital that the statutory duty of monitoring land use changes be performed in a more in-depth manner. It could be recommended to analyse the land use changes for a longer period (year-on-year) in a single document, for example since the obligation was implemented in 2000. When preparing a document for 2017, voivode marshals should then analyse the land use changes year by year, for 17 years back. Another tool that could aid the land use change monitoring process is the statistical modelling, which was presented in more detail in Noszczyk et al. [2017]. The statistical models facilitate determining a trend and taking corrective actions, if necessary. These may include limiting the number of permits to convert the land from the agricultural production to other uses or adequate shaping of region's spatial policy.

\section{Acknowledgements}

The author would like to thank Professor Józef Hernik for assistance, valuable tips, replying to my questions, and clarifying doubts.

This research was financed by the Ministry of Science and Higher Education of the Republic of Poland, projects No. BM - 4317/KGPiAK/2017 and DS 3371/KGPiAK/2017.

\section{REFERENCES}

1. Analiza, 2014. Analiza struktury agrarnej i sposobu użytkowania gruntów w województwie warmińsko-mazurskim na dzień 1.01.2014 r. 2014. Urząd Marszałkowski Województwa Warmińsko-
Mazurskiego, Dostępny pod adresem: http://atlas. warmia.mazury.pl/index.php/opracowania/44analizy-agrarne-2014 (access: 7.09.2017 r.).

2. Analiza, 2016a. Analiza struktury własności i sposobu użytkowania gruntów w województwie kujawsko-pomorskim w 2015 roku. 2016. Urząd Marszałkowski Województwa KujawskoPomorskiego, Dostępny pod adresem: http:// geoportal.infoteren.pl/AnalizaStrGruntWojKujPom2010-2015.pdf (access: 7.09.2017 r.).

3. Analiza, 2016b. Analiza struktury własności i sposobu użytkowania gruntów w województwie śląskim w 2016 roku. 2016. Urząd Marszałkowski Województwa Śląskiego, Dostępny pod adresem: http://www.slaskie.pl/zalaczniki/2016/05/20/ 1463732902/1463733025.pdf (acces: 26.08.2017 r.).

4. Bouma J., Varallyay G., Batjes N.H. 1998. Principal land use changes anticipated in Europe. Agriculture Ecosystems \& Environment, 67, 103-119.

5. Bürgi M., Straub A., Gimmi U., Salzmann, D. 2010. The recent landscape history of Limpach valley, Switzerland: considering three empirical hypotheses on driving forces of landscape change. Landscape Ecology, 25, 287-297.

6. Cegielska K., Kudas D., Różycka-Czas R., Salata T., Szylar M. 2017. The analysis of land cover macrostructure in the suburban area of Krakow. Geomatics, Landmanagement and Landscape, 2, 47-60.

7. Chaba D. 2016. Local government during the transformation in Poland. In: Contemporary trends in international relations: politics, economics, law. Proceedings of VI Annual International ScientificPractical Conference, Lviv 24 Sep 2016, 11-19.

8. Chen L., Dirmeyer P.A. 2017. Impacts of LandUse/Land-Cover Change on Afternoon Precipitation over North America. Journal of Climate, 30, 2121-2140.

9. Dannenberg P., Kuemmerle T. 2010. Farm Size and Land Use Pattern Changes in Postsocialist Poland. Professional Geographer, 62, 197-210.

10. Dawidowicz A. 2010. Wykorzystanie powiatowych zestawień zbiorczych danych objętych ewidencją gruntów i budynków w procesie zbierania informacji o stanie rozwoju gminy wiejskiej. Przegląd Geodezyjny, 3, 14-23.

11. Decree of 2 February 1955 on the land and property register. 1955. Journal of Laws of 1955, No. 6, item 31 and 32.

12. Deng X., Li Z. 2016. A review on historical trajectories and spatially explicit scenarios of land-use and land-cover changes in China. Journal of Land Use Science, 11, 709-724.

13. Instrukcja Ministra Gospodarki Komunalnej z dnia 8 września 1956 r. w sprawie zakładania i prowadzenia ewidencji gruntów, zasad sporządzania wykazów gruntów oraz opłat za odrysy z map i za odpisy i wyciągi z rejestrów i dokumentów stanowiących część operatu ewidencyjnego na obszarze m. st. Warszawy, m. Łodzi i miast stanowiących 
powiaty, Monitor Polski Nr 98, poz. 1135.

14. Instrukcja Ministra Rolnictwa $\mathrm{z}$ dnia 21 kwietnia 1955 r. w sprawie zakładania i prowadzenia ewidencji gruntów, zasad sporządzania wykazów gruntów oraz opłat za odrysy z map i za odpisy oraz wyciągi z rejestrów i dokumentów stanowiących część składową operatu ewidencyjnego na obszarze gromad, osiedli i miast nie stanowiących powiatów, Monitor Polski Nr 38, poz. 379.

15. Irwin E.G., Geoghegan J. 2001. Theory, data, methods: developing spatially explicit economic models of land use change. Agriculture Ecosystems \& Environment, 85, 7-23.

16. ISAP, 2017. Online Database of Legal Acts. Available at: http://isap.sejm.gov.pl/index.jsp (accessed: 24.08.2017).

17. Karimi M., Mesgari M.S., Sharifi M.A., Pilehforooshha P. 2017. Developing a methodology for modelling land use change in space and time. Journal of Spatial Science, 62(2), 261-280.

18. Kleemann J., Baysal G., Bulley H.N.N., Furst C. 2017. Assessing driving forces of land use and land cover change by a mixed-method approach in north-eastern Ghana, West Africa. Journal of Environmental Management, 196, 411-442.

19. Kluba M. 2013. Land management as an expression of change in agriculture on the example of the Kuyavian-Pomeranian Voivodeship. Acta Universitatis Lodziensis. Folia Geographica Socio-Oeconomica, 13, 179-198 (in Polish).

20. Krasowicz S., Oleszek W., Horabik J., Dębicki R., Jankowiak J., Stuczyński T., Jadczyszyn J. 2011. Rational management of the soil environment in Poland. Polish Journal of Agronomy, 7, 43-58 (in Polish).

21. Łowicki D. 2008. Land use changes in Poland during transformation Case study of Wielkopolska region. Landscape and Urban Planning, 87, 279-288.

22. Noszczyk T., Rutkowska A., Hernik J. 2017. Determining Changes in Land Use Structure in Malopolska Using Statistical Methods. Polish Journal of Environmental Studies, 26(1), 211-220.

23. Olszewski R., Gasiorowski J., Hajkowska M. 2015. Spatio-Temporal Modeling as a Tool of the Decision-Making System Supporting the Policy of Effective Usage of EU Funds in Poland. In: Gervasi O. et al. (eds) Computational Science and Its Applications - ICCSA 2015. Lecture Notes in Computer Science, 9157, pp. 576-590. Springer, Cham.

24. Poławski Z. 2009. Land use changes in Poland during last two centuries. Teledetekcja Środowiska, 42, 69-82 (in Polish).

25. Public Information Bulletin of the Małopolskie Voivodeship Marshal Office, 2017. Available at: https://bip.malopolska.pl/umwm/Article/get/ id,747444.html (access: 7.09.2017).

26. Regulation of the Minister of Regional Development and Construction of 29 March 2001 on the land and property register (unified text: Journal of Laws of 2016, item 1034 as amended).
27. Salata T., Prus B., Janus J. 2015. Planning as trigger for land use changes. Proc. 14th International Scientific Conference: Engineering for Rural Development, 729-734.

28. Schneider L.C., Pontius R.G. 2001. Modeling land-use change in the Ipswich watershed, Massachusetts, USA. Agriculture Ecosystems \& Environment, 85, 83-94.

29. Stephenne N., Lambin E.F. 2001. A dynamic simulation model of land-use changes in Sudano-sahelian countries of Africa (SALU). Agriculture Ecosystems \& Environment, 85, 145-161.

30. Struktura własności i sposobu użytkowania gruntów w województwie mazowieckim. 2016. Urząd Marszałkowski Województwa Mazowieckiego, Dostępny pod adresem: http://www.geodezja.mazovia.pl/pliki/prezentacje/analiza_swsiwg_2016.pdf (access: 7.09.2017 r.).

31. Act 1975. Ustawa z dnia 28 maja 1975 r. o dwustopniowym podziale administracyjnym Państwa oraz o zmianie ustawy o radach narodowych, Dz.U. 1975 nr 16 poz. 91.

32. Act 1989. Ustawa z dnia 17 maja 1989 r. Prawo geodezyjne i kartograficzne (tekst jedn. Dz.U. z 2016 r., poz. 1629 ze zm.).

33. Act 1998a. Ustawa z dnia 24 lipca 1998 r. o wprowadzeniu zasadniczego trójstopniowego podziału terytorialnego państwa, Dz.U. 1998 nr 96 poz. 603.

34. Act 1998b. Ustawa z dnia 24 lipca 1998 r. o zmianie niektórych ustaw określających kompetencje organów administracji publicznej - w związku z reformą ustrojową państwa, Dz.U. 1998 nr 106 poz. 668.

35. Act 2000. Ustawa z dnia 21 stycznia 2000 r. o zmianie niektórych ustaw związanych $\mathrm{z}$ funkcjonowaniem administracji publicznej, Dz.U. 2000 nr 12 poz. 136.

36. Van Paassen A., Roetter R.P., Van Keulen H., Hoanh C.T. 2007. Can computer models stimulate learning about sustainable land use? Experience with LUPAS in the humid (sub-)tropics of Asia. Agricultural Systems, 94, 874-887.

37. Van Vliet J., De Groot H.L.F., Rietveld P., Verburg P.H. 2015. Manifestations and underlying drivers of agricultural land use change in Europe. Landscape and Urban Planning, 133, 24-36.

38. Woch F. 2014. Ocena zmian wykorzystania przestrzeni wiejskiej w Polsce. Polish Journal of Agronomy, 18, 52-62.

39. Woch F., Woch R. 2014. Zmiany użytkowania przestrzeni wiejskiej w Polsce. Infrastruktura i Ekologia Terenów Wiejskich, I/1/2014, 111-124.

40. http://wgik.dolnyslask.pl/web/start/dsip/bazytematyczne/struktura-uzytkowania-gruntow

41. http://www.slaskie.pl/strona_n.php?jezyk=pl\&gru $\mathrm{pa}=3 \& \mathrm{dzi}=1279014625 \& \mathrm{id} \_$menu$=533$

42. http://wgik.dolnyslask.pl/wojewodzkiezestawienia 